\title{
The Importance of Anaesthesia in a Leprosy Control Programme
}

\author{
RICHARD S. BUKER, M.D., M.P.H. \\ KHONKAEN, Thailand
}

Large scale leprosy control programmes are now being undertaken in several parts of the world, as in Nigeria, Thailand, certain sections of India and other places. These are bringing into focus definite problems which are resulting in the failure completely to cradicate the disease even after io to i 5 ycars of concentrated effort. To state the problem simply the control of leprosy is a matter of finding the cases and giving treatment long enough to bring about negative bacterial smears and to prevent rclapses. 'This also requires a continuing publicity effort as a permanent part of the programme. In the finding of all the cases, RODRIGUEz, writing about the control programme of the Philippines, has pinpointed the main obstacle. He says, 'The main obstacle, however, is the lack of a simple diagnostic test in leprosy, comparable to the tuberculin test combined with photoflorography in tuberculosis and serology tests in yaws, which would make mass examination for leprosy much less expensive and time consuming'. ${ }^{37}$

It is my contention that we have just such a diagnostic test in the determination of anaesthesia to light touch. In making a survey of a population for leprosy many cases are obvious to most people, and even to children. It is not these cases but the early cases and those in which the differential diagnosis is difficult for which a simple but absolutely sure sign or symptom is desirable. This symptom or sign must be applicable for the use of paramedical workers. Most field leprosy work has to be done and is donc by paramedical workers. This symptom or sign is anaesthesia to light touch. One may say categorically "with anaesthesia you have leprosy, without it you do not have it'. According to COCHRANE ${ }^{12}$ it is one of the cardinal evidences of leprosy, the other is the demonstration of the presence of $M$. leprae in the tissues. If leprosy is to be controlled, a method by which it can be definitely diagnosed before skin smears are positive must be available to the field worker. The proper and careful examination for anaesthesia will often reveal the presence of leprosy one to two years or longer before the skin smears are positive. It is true, that with the present level of civilization and the general lack of knowledge of leprosy by the public, most people with early leprosy will not believe they have the disease and therefore do not accept the treatment. This is a matter for propaganda and education.

It is an excellent method for differentiating all similar skin diseases, poliomyclitis and beriberi. Gliomas and other tumours of the nervous system, syringomyelia, and the lateral femoral syndrome are so rare that 
they are not important in a large control programme. It would be far better to treat one to five such cases as leprosy than to neglect treating several hundred leprosy cases. Such of these rare cases that happened to be discovered in our field work by the paramedical workers, were readily recognized as being 'abnormal' leprosy cases and have been reported at once to competent medical personnel. Certain tribes in Africa develop a rather limited form of anaesthesia, that is they recognize the fact that they are being touched but cannot pinpoint the place. These people can feel more the process of cleaning and trimming ulcer edges than do the usual leprosy patients. Many of these tribal people however do develop typical anacsthesia.

'The pathological basis for this early clinical sign has been studied by many: ${ }^{1},{ }^{4},{ }^{5},{ }^{7},{ }^{8},{ }^{9},{ }^{10},{ }^{13},{ }^{16},{ }^{17},{ }^{18},{ }^{19},{ }^{21},{ }^{22},{ }^{23},{ }^{25},{ }^{26},{ }^{27},{ }^{28},{ }^{34},{ }^{38},{ }^{40},{ }^{42}$, ${ }^{43},{ }^{45},{ }^{46}$.

Observation by DEHIO ${ }^{13}$ and KLINGMÜLLER ${ }^{28}$ and GASS $^{18}$ showed that carly lesions revealed an inflammatory infiltrate at places which often took the form of branching strands, like the branching fibres of cutaneous nerves. Silver impregnated sections showed argentophilic granules in the basal layers which reveal the disappearance of the nerve twigs after they entered the epithelium. In maculoanaesthetic lesions the subepithelial part of the corium shows either a complete loss of nerve fibres or only rare fibres embedded in the filtrate. In very early lesions marked alteration to absent nerve fibres in the sub-epithelium is noticed. Fragmentation is seen, the fibres breaking into wavy and twisted segments. As the disease advanced the number of fibres in the mid-corium were far less and more fragmentation was present. All fibres show fusiform swelling along their course.

Changes in Meissner's corpuscles have been described by HOGGAN and SSUDAKEWITSGH as quoted by TORSSUJEW ${ }^{42}$ and ALVAREZ ${ }^{1}$. CRIECO ${ }^{19}$ described the frequent involvement of the nerves of all skin lesions. DECOUD $^{7}$ claimed that nerve injury is a constant feature of all types of leprosy, though destroyed more rapidly in tuberculoid lesions. $\mathrm{GAss}^{18}$ has shown by biopsy and clinical testing that the skin is often anaesthetic but as the hair follicules go deeper there may be some tactile sensation if the hairs only are stimulated. KHANOLKAR and COCHRANE ${ }^{26}$ record under their histological findings; (I) for lepromatous macules 'The bacilli are readily found in the nerves and follow closely the contours of the nerve fibres. They show a characteristic linear distribution in the longitudinally cut nerves;' (2) the tuberculoid macule, 'The essential feature of the histological picture is a tendency of the inflammatory reaction to settle down in discrete foci, in and around the cutaneous nerve twigs.' Clinical application of the histological findings have been made by many, sometimes without realizing the correlation and sometimes with intentional application. GASS and BALASUBRAMANYAN ${ }^{18}$ have published very detailed cxperiments on the skin of leprosy patients. Realizing that the earliest outward manifestation of leprosy is anaesthesia to light touch, though the 
anacsthesis may not be in the macules or plaques and the very earliest evidence of anaesthesia is the patient's inability to locate the exact point of being touched; we required the demonstration of anacsthesia in a person before making the definite diagnosis of leprosy.

Our first application of this knowledge in expensive survey work was in $193^{6-1939}$ in Eastern Burma. ${ }^{6}$ I personally supervised the majority of the examinations which were done by paramedical workers. Of 9,956 people examined, over I,ooo were tested for anaesthesia. A definite diagnosis of leprosy was made on 609 cases all of whom had anaesthesia. From $195^{\mathrm{I}-1956}$ in 'Thailand many paramedical workers were trained in the diagnosis and treatment of leprosy. During that time in the North-East of 'Thailand over I 0,000 leprosy cases were registered. All early cases were determined by examining for anacsthesia. After $\mathrm{I}$ and $\mathrm{I}_{2} \frac{1}{2}$ years of work by the paramedical workers, DR. COCHRANE, a leprologist of no mean reputation and who doubted the ability of paramedical workers being able to diagnose leprosy by this method only, made a careful survey trip in the areas where these people were working. He found not a single case diagnosed as leprosy as not having the disease. The patients were all positive by his own criteria.

In over 30 years of leprosy experience I have never found a case of leprosy without cvidence of anacsthesia. There are certain tribes or one tribe in Africa running through Northern Nigeria and Ghana that have leprosy patients that are nearly an exception. In a special trip to this area several patients were demonstrated with marked leprosy and their only disturbance of sensation was inability to pin-point the place of contact. Except for this unusual tribal characteristic, anaesthesia is universal in all leprosy patients. From time to time articles appear referring to clinical symptoms stating there are no neural symptoms or involvement ${ }^{32},{ }^{41}$. Realizing that it is often assumed that anaesthesia may or may not be present, I contacted the medical officer in charge of the leprosy outpatient department of the Vellore Medical Centre, in South India and requested permission to examine every leprosy patient listed in their files in whom the history definitely recorded there was no anaesthesia present. This courtesy was kindly granted. At the time of my arrival all such patients possible were called to the outpatient department. Under the careful eye of the Chief of the department anaesthesia was easily demonstrated on all cases.

The method of testing is important. COCHRANE ${ }^{12}$ in his excellent book advises the use of a feather or cotton. GAss $^{18}$ used a feather. Whereas experts may use a variety of things I have found it unwise to allow paramedical workers to use either cotton, or feathers, or pins or needles. Feathers are advised against because there are too many varieties, cotton can give false positives and pins and needles miss many early cascs. Because of the availability and satisfactory consistency we use a piece of paper, a leaf or blade of grass. The stalk portion of the grass or leaf and cardboard are too stiff and early anaesthesia may be missed. Just touching 
the skin or a light stroke of $1 \mathrm{~cm}$. is the right way to test. Longer strokes often miss small areas of anaesthesia. Whereas some macules are anacsthetic a great many are not. Anaesthesia may occur anywhere on the body. Over 50 per cent of early cases have it first on the feet or ankle region. Palms of the hands and soles of the foot, callouses and scars are not tested. The reason why most people are anaesthetic first over the lower extremities, I assume to be due to the fact that leprosy first enteres the body through abrasions and microscopic lacerations in the skin of the feet. This can be proved only by deduction. 'The patient should be blindfolded always. 'There is the theoretical possibility of $M$. leprae after entering the body, advancing so rapidly (multiplying and spreading) in a completely non-immune person that infiltration of the skin and/or a leprosy reaction may take place with positive skin smears; these all may develop within I-4 months before anacsthesia has a chance to become manifested. Actually I have never seen such a thing happen.

\section{S U M M A R Y}

The earliest invasion of the body by $M$. leprae results in nerve tissue tocing first selected. The natural symptoms which develop are possible parasthesias and anaesthesia to light touch. This, in fact, is what happens as shown by the examination of hundreds of contacts of leprosy patients who have not developed obvious macules, infiltration, or early paralysis. The test is simple, proficiency being acquired rapidly by lay workers. It can be performed in the surveys of control programmes vithout consuming undue time. With anaesthesia the patient has leprosy, without it the patient has no leprosy.

\section{Bibliography}

I. Alvarez, I. I.., PUChol, J. R. and rodriquez, P. A. P. A portacion al Conociminto Histopatholgice del Sistema Nervioso Perifico enla lepra. Int. Jour. Leprosy, Vol. I6, pp. 459-464 ( 1948$)$.

2. Andersen, J. G., Plantar Ulcers in Leprosy. Leprosy Review, Vol. 32, No. I, pp. i6-27 (I96I).

3. ARgenta, G., Neurological Psychological and Psychopathological aspects of Leprosy - A Cliniconosographic contribution concerning 75 cases. Monograph in Italian Editrice Colis Napoli ig6 I. Abstract Leprosy Review, Vol. 33, No. 3, pp. 269-27 I (I962).

4. Balasubramanyan, M., Jayaraj, A. D., and Gass, H. H. An Improved Histological Method for Examination of Cutaneous Nerves in Leprosy. Leprosy Review, Vol. 25, pp. 83-96.

5. BINford, c. H., Predilection of M. Leprae for Peripheral Nerves. Leprosy Briefs, Vol. I3, No. 2, Feb., I 962. Johns Hopkins Univ. Symposium on Research in Leprosy, May I 96 I, 8-1 0.

6. Buker, R. s., The Epidemiology of Leprosy with Special Reference to Findings in Kengtung State, s.s.s. Burma. Thesis in Harvard School of Public Health, June I 94 I, p. 82.

7. Castane, decoud a., Comparative Study of the Nerve branches of the Skin in Tuberculoid and Lepromatous Leprosy. Int. Jour. Leprosy, Vol. i6, pp. $45^{\mathrm{I}-45^{8}}$ ( (948).

8. Causey, G., The Cell of Schwann. Edinburgh \& London E.V.S. Livinstone Ltd (1960).

9. Chatterjee, s. N., The Diagnosis of Leprosy and its Difficulties. Fourth Biennial Meeting of the Indian Assoc. of Leprologists, I 5/1 2/1959. Leprosy in India, Vol. 32, No. I, p. 5.

io. Chatterjee, s. N., The Mechanism of the Neural signs and Symptoms of Leprosy. Inter. .Journ. of Leprosy, Vol. 23, p. I (1955). 
I I. cochrane, r. (i., 'The I eprosy Research Fund. Leprosy Review, Vol. 29, No. 4, pp. 236-237 (1958).

12. cochrane, R. (., leprosy in 'Theory and Practice, 1959. Bristol: John W'right \& Sons Led. p. 143 .

13. рвно, Uber die lepra anesthesica und den Pathogenitschen /usammenhangihrer Krankheitsercheinungen. Reprint in English I eprosy in India, Vol. 24, pp. 78-83 (1952).

14. DhARMENIJRA and ChATterjee, s. N., Maculo-Anesthetic I.eprosy. Its diagnosis and classification. Leprosy Review, Vol. 33, No. 2, pp. I o6-1 I8 (1962).

I5. Domingues, v. M., Early Diagnosis of I.eprosy by Study of the Sweat Responses to Ionophoresis with Parasympathomimeties. Bul. Who, Vol. 26, pp. 227-3I.

I6. Frre, G. I., I eprosy from the Histologic Point of View. Archives of Pathology, Vol. 3.5, pp. 6 I I -644 ( I 943$)$.

I 7. FRITsciil, f. P., The Pattern of Sensory I oss in Iceprosy and its Significance in the Pathogenesis of I.eprotic Neuritis. Leprosy Review, Vol. 27, No. 4, pp. I5I-I6I (1956).

I 8. GASs and BAKASYBRAGNABYAN, (hanges in the Cutaneous Nerves in Ieprosy. Int. Jour. of I.eprosy, Vol. 22, pp. 31-40 (1953).

I9. (irifco, v., Aspectus Histologicos das Nervrites na I.eprs. Rev. Bras. I.ep., Vol. 4, pp. $271-303$, Reprint in E.ng. Int. Jour. I.ep., Vol. 6, pp. $361-70$ (1938).

20. James, 1). (. \& Jopling, w. н., Sarcoidosis and I.eprosy. I.ep. in Ind., Vol. 35 (1963). pp. I-I 8 Reprint from Jour. 'Trop. Níed. \& Hyg. 64 (I96I).

2I. Jayaraj, A. P., Chaunhury, I). s., Studies on the Neurohistological changes in the Meisner Corpuscle in Leprosy. Leprosy Review, Vol. 32, No. 3, pp. 167-69 (1961).

22. Jayaraj, A. P., Chaudhury, I). s., Studies on the Structure and Functions of the Pappillary Ridges in the I)igital Skin in I.eprosy. Leprosy Review, Vol. 33, No. I, pp. 41-4 (1962).

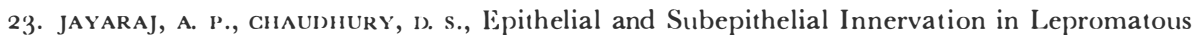
Leprosy. Lep. in Ind., Vol. 33, No. 3, pp. I67-9 ( เ962).

24. JOPI.ING, w. H., Borderline (Dimorphous) Leprosy Maintaining a Polyneuritic Form for 8 years. Trans. R.S. Trop. Med. \& Hyg., Vol. 50, No. 5, pp. 478-80 ( 1956).

25. Khanolkar, v. R., Studies in the Histology of Early Lesions in Leprosy. Ind. Council of Med. Res. Special Report Series, No. I9 (I95I).

26. khanolkar, v. R. and cochrane, R. G., The Dimorphous Macular Lesion in Leprosy. Ind. Jour. Med. Scien., Vol. ı, No. 7, pp. 499-505 (1956).

27. Khanolkar, v. R., Perspectives in Pathology of Leprosy. Ind. Jour. Medical Sciences, Vol. 9, p. I (I 955).

28. кhanolkar, v. R., Diagnosis of Leprosy. Leprosy Review, Vol. 32, No. 3, pp. I58-i 66 (I96 I)

29. Klingmuller, v., Die Lepra Handbuch der Haut und Geskhlechtskrankheiten io pt 2.

30. Langerhans, P., I 868 Quoted by Weddell G., Palmer E., and Pallie, W. Nerve Endings in Mammalian Skin. Biological Rev., Vol. 30, pp. I54-195 (I955).

3I. minato, J., Peripheral Nerve Involvement in Upper I.imbs of I.eprosy Patients. Leprosy Review, Vol. 30, I : I 5 I 959 (Vii Int. Cong. of Leprosy).

32. mukerjee, N., and ghosh, s., Familial Leprosy. Ind. Med. Ass., Vol. 31, No. 3, pp. I 29-31 (I 958$)$.

33. Nishura, m., The Electronmicroscopic Basis of the Pathology of Leprosy. Int. Jour. of Leprosy, Vol. 28, No. 4, pp. 351-400 (I960).

34. A New Sensation. Editorial. J.A.M.A., Vol. i 76, pp. 944-5 (196ı).

35. PRICE, E. w., The Prevention of Plantar Ulcer in Leprosy. Leprosy Review, Vol. 34, No. I, pP. I6-25 (I963).

36. Price, E. w., The Innervation of the Hand in relation to Leprosy. Leprosy Review, Vol. 29, No. 4, pp. $215^{-221}$ (1958).

37. Rodriquez, J. N., Evaluation of Leprosy Control Programme of the Philippines. Int. Jour. of Leprosy, Vol. 30, No. 2, p. I I5 ( I 962 ).

38. The Schwann Cell - Editorial J.A.M.A., Vol. I73, pp. ı667-8 (1960).

39. silva, F. B., El Sindrome Neural Leprosa. Revista Peruana de Salud Publica Lima, 5: 2, 3, 4 (1956); 6: I (1957) 447. Abst. Leprosy Review, 30: I 99. 
40. stein, A. A., Specific Affections of Follicular Apparatus of the Skin in Leprosy. Int. Journ. of Leprosy Review, Vol. 8, pp. 299-306 (1940)'.

41. susman, I. A., 'The pattern of I.eprosy in Gambia, West Africa. Leprosy Review, Vol. 34, No. 2, pp. 83-94 (1963).

42. Torssujew, N. A., Morphologic Changes of the Cutaneous Nerves in Leprosy. Int. Jour. of Lepr., Vol. 8, pp. 467-480 (1940).

43. Weddeli, (i., The anatomy of Cutaneous Sensibility. British Med. Bulletin, Vol. 3, pp. 167-1 72 (1945).

44. Weddeli, (i., and palmer, F., 'The Pathogenesis of Leprosy. Leprosy Review, Vol. 34, No. 2, pp. $57-6$ r ( 1963$)$.

45. Wediel.t, (., Pallik, W., PAimer, E., The Morphology of Peripheral Nerve Terminations in Skin. Quat. J. of Micr. Science, Vol. 95, pp. 483-501 (1954).

46. worT, o., Das Ruckenmark die peripheren Nerven und die Hautllecken bei de Lepra Maculo Anesthetica. Reprinted in English. Lep. in India. Vol. 24, Ip. 133-55 (1952). 